\title{
Fungsi Frasa Orang Benar Akan Hidup Oleh Iman Berdasarkan Surat Roma dan Implikasinya Bagi Orang Percaya Masa Kini
}

\author{
Firman Firman, Armin Sukri
}

Sekolah Tinggi Filsafat Theologia Jaffray Makassar

\begin{abstract}
Abstrak
Tujuan Penulisan skripsi ini adalah: Pertama, untuk menjelaskan fungsi frasa orang benar akan hidup oleh iman berdasarkan Surat Roma. Kedua, untuk memberikan suatu implikasi berdasarkan kajian tentang frasa orang benar akan hidup oleh iman bagi orang-orang percaya masa kini. Metode penelitian yang digunakan dalam penulisan skripsi ini adalah metode Hermeneutik Eksegesis kualitatif. Metode ini menentukan genre teks, menentukan konteks sebelum dan sesudah teks, kemudian menguraikan struktur teks dan menganalisa teks tersebut dengan menggunakan metode pengumpulan data melalui penelitian kepustakaan dengan menggunakan Alkitab sebagai sumber utama, dan didukung dengan kamus, buku-buku dan jurnal serta berbagai literatur berhubungan dengan pembahasan penulis. Dari hasil penelitian ini penulis menarik kesimpulan: Pertama, fungsi frasa orang benar akan hidup oleh iman adalah sebagai penanda status serta hubungan seseorang yang telah dibenarkan Allah dalam Kristus Yesus. Kedua, bagi setiap orang percaya yang telah dibenarkan Tuhan, seharusnya berjalan dengan iman selama dalam kehidupannya dan setiap orang yang beriman kepada Tuhan harus mempercayai Tuhan secara terus-menerus selama dalam hidupnya.
\end{abstract}

Kata-Kata Kunci: Orang Benar, Kebenaran, Pembenaran, Iman, Percaya, Injil.

\section{Pendahuluan}

\section{Latar Belakang Masalah}

Bagi orang-orang percaya, iman tentulah sudah tidak asing lagi untuk didengar, sebab pengajaran mengenai iman tentunya telah banyak diperdengarkan dalam khotbah-khotbah atau pengajaran-pengajaran di dalam gereja. Pada dasarnya iman memiliki pengertian sebagai rasa aman akan sesuatu hal yang diharapkan atau sesuatu keyakinan yang telah dipegang teguh sejak percaya, secara sederhanaya iman adalah harapan yang dipegang teguh. Harun Handiwijono berpendapat:

Iman berasal dari kata kerja aman, yang berarti "memegang teguh" kata ini dapat muncul dengan bentuk yang bermacam-macam, umpanya, dalam arti "memegang teguh kepada janji” seseorang, karena janji itu dapat dianggap teguh atau kuat, sehingga dapat diamani, 
dipercaya jika diterapkan kepada Tuhan Allah, maka kata iman berarti, bahwa Allah harus dianggap sebagai yang Teguh atau Yang Kuat. ${ }^{1}$

Dalam Perjanjian Baru, iman merupakan dasar dari segala sesuatu yang diharapkan dan bukti dari apa yang tidak dilihat (Ibrani 11:1), ini merupakan definisi iman yang sangat indah, karena iman merupakan bukti soal apa yang tidak dilihat mata sekaligus juga dasar dari apa yang diharapkan. Sebagaimana pendapat di atas, iman kekristenan sudah seharusnya menunjuk ke arah Tuhan yang menjadi dasar dari pada iman itu sendiri. Pernyataan yang sama juga diungkapkan oleh James M. Boice bahwa, "dalam konteks ajaran alkitabiah iman dapat disadari karena iman itu adalah iman kepada Allah yang dapat dipercayai, yang menyatakan diri-Nya secara handal." 2 Ini menunjukkan pengertian iman adalah sebagai kepercayaan seseorang secara penuh atau total kepada Tuhan.

Dalam surat Yakobus dikatakan ada iman yang mati atau iman tanpa perbuatan pada hakekatnya adalah mati. Dengan kata lain iman yang seperti itu tidaklah berguna. Yakobus memberikan perumpamaan seperti ada orang yang berkata, selamat jalan, kenakanlah kain panas dan makanlah hingga kenyang kepada orang yang tidak memiliki pakaian dan makanan (Yakobus 2:14-17). Perumpamaan yang Yakobus berikan menunjukkan gaya hidup umat Kristen pada masa Yakobus yang mungkin sering melakukan perbuatan demikian, seolah bersimpati namun tidak memberikan bantuan. Karena iman yang dimaksudkan dalam surat Yakobus ini adalah iman orangorang yang telah percaya atau iman orang Kristen, sebagaimana yang disampaikan oleh Gunning bahwa,

Tidak ada gunanya kalau seseorang mempunyai iman yang tidak disertai perbuatan; iman itu sendiri tidak dapat menyelamatkan atau dengan perkataan lain, iman itu takkan diterima Allah. Yakobus hendak membuktikan dalil ini dengan dua cara (15-17 dan18-26). Ia mulai dengan perbandingan dari hidup sehari-hari. Mengucapkan selamat jalan (syaloom!), selamat makan dsb, adalah omong kosong, kalau orang untuk siapa ucapan itu ditujukan, tidak mempunyai makanan dan sebagainya, sedangkan orang yang mengucapkannya tidak menyertai ucapannya itu dengan pertolongan yang nyata. ${ }^{3}$

Melalui peryataan di atas maka dapat disimpulkan bahwa pengertian iman mulai bergeser dari pengertian awalnya yang memiliki fokus pada kepercayaan penuh kepada Allah dan berpengang teguh kepada-Nya. Artinya ada beberapa pemahaman yang keliru dari apa yang firman Tuhan sampaikan mengenai Iman. Iman memang berkaitan dengan perbuatan, kaitan ini memang dapat dibedakan namun tidak dapat dipisahkan. ${ }^{4}$ Meskipun demikian terlihat seringkali orangorang Percaya salah mengartikan iman dan perbuatan yang kemudian menganggap iman saja tidak cukup dan menganggap perbuatanlah yang menyempurnakan iman. Hal yang sama juga dikatakan oleh James M. Boice, dia berkata bahwa,

Terjadi sejumlah besar kebingungan tentang iman hanya karena kita secara tidak dapat dieelakkan menerapkan kata itu kepada banyak orang yang tidak layak dipercaya.

\footnotetext{
${ }^{1}$ Harun Hadiwijono, Iman Kristen (Jakarta: BPK Gunung Mulia, 2007), 17.

2 James Montgomery Boice, Dasar-Dasar Iman Kristen (Surabaya: Momentum, 2015), 456.

3 J. J. W. Gunning, Tafsiran Alkitab Surat Yakobus (Jakarta: BPK Gunung Mulia, 2015), 30.

${ }^{4}$ R. C. Sproul, Kebenaran-Kebenaran Dasar Iman Kristen (Malang: Seminari Alkitab Asia Tenggara,
} 2000), 255. 
Contohnya, kita berbicara tentang melakukan sesuatau berdasarkan "kepercayaan." Tetapi dalam hal apapun yang penting, kita tidak menerima begitu saja perkataan dari Individu itu. Kita menuntut perbuatan, kontrak-kontrak, dan jaminan-jaminan tertulis lainnya... maka tidak heran jika iman sering dilihat sebagai angan-angan belaka. ${ }^{5}$

Iman sering dilihat sebagai angan-angan semata memberikan pengertian bahwa iman pandangan mengenai iman hanya sebatas pengertian saja dan tidak sampai kepada penerapan dalam kehidupan. Dalam surat Paulus kepada jemaat di Roma banyak membahas persoalan iman, seperti manusia yang dibenarkan karena iman (3:21-31), Abraham yang dibenarkan karena Iman (4:1-25), pembenaran oleh Iman (5:1), dan kebenaran karena iman (10:4-15). Dengan adanya pemahaman yang telah bergeser mengenai pengertian iman menyebabkan pandangan-pandangan tentang ajaran Paulus mengenai iman juga akan bergeser dari makna sesungguhnya. Sebab, Iman adalah unsur penting dalam pengajaran Paulus, khususnya dalam ajaran mengenai pembenaran dalam surat Roma, Salah satu pembahasan iman yang bergeser dari pemahaman yang seharusnya, adalah pernyataan Paulus mengenai Injil yang di dalamnya nyata kebenaran Allah, yang bertolak dari iman dan memimpin dari iman, sebab ada tertulis: "orang benar akan hidup oleh iman" (Roma $1: 17)$.

Ada perbedaan dalam menerjemahakan frasa yang digunakan oleh Paulus dalam Roma 1:17 ini. Sebagai contoh dalam terjemahan Alkitab dalam bahasa Indonesia atau Terjemahan Baru adalah "orang benar akan hidup oleh iman" dan dalam terjemahan KJV diterjemahakan sebagai "the just shall live by faith" atau jika diterjemahkan bisa menjadi seperti ini "hanya akan hidup dengan iman." Hasan Sutanto memberikan terejemahan bagian ini dengan terjemahan harafiah yang berbunyi "(orang) yang mempunyai hubungan benar dengan (dengan Allah) oleh iman akan hidup." "Ini merupakan contoh sederhana, bahwa ada perbedaan yang cukup signifikan dalam menerjemahkan frasa yang digunakan Paulus di sini, sehingga ini membuat pengertian dari apa yang Paulus maksudkan akan bergeser dari makna yang seharusnya.

Beberapa penafsiran dari tafsiran Alkitab Wycliffe memberikan pertanyaan mengenai ini, yaitu "satu masalah kecil adalah: Apakah orang yang dibenarkan oleh iman akan hidup, ataukah orang benar itu hidup oleh iman?"7 Selain itu, para penafsir memberikan pernyataan bahwa kalimat orang benar akan hidup oleh iman memberikan kesan yang berbeda, yaitu "seoarang yang benar dengan cara yang lain tidak dapat hidup sekalipun ia memenuhi syarat untuk menjadi orang benar. Iman disebutkan disini untuk menekankan bahwa iman mutlak diperlukan orang untuk dapat menjadi benar." 8

Dave Hagelberg, seorang yang menuliskan buku Tafsiran Surat Roma dari bahasa Yunani bependapat bahwa, frasa "orang benar akan hidup oleh iman" yang ditulis dalam Terjemahan Baru dianggap keliru, karena tidak mempertimbangkan konteks ayat ini. Dave, mengatakan bahwa apa yang diterjemahkan dalam Terjemahan Baru untuk frasa ini tidak jauh berbeda dengan ajaran yang dimiliki oleh agama lain, hal ini dikarenakan Terjemahan Baru memberikan pengertian bahwa

${ }^{5}$ Boice, $453-454$.

${ }^{6}$ Hasan Sutanto, Perjanjian Baru Interlinear Yunani-Indonesia dan Konkordansi Perjanjian Baru (PBIK) Jilid I (Jakarta: Lembaga Alkitab Indonesia, 2014), 810.

${ }^{7}$ Charles F. Pfeiffer dan Everett F. Harrison, ed., The Wycliffe Bible Commentary Volume 2 (Malang: Gandum Mas, 2015), 1136.

${ }^{8}$ Charles F. Pfeiffer dan Everett F. Harrison, ed., The Wycliffe Bible Commentary Volume 3 (Malang: Gandum Mas, 2013), 668. 
orang benar ini akan mengatur hidup mereka menurut iman mereka kepada Allah atau dewi-dewi mereka. ${ }^{9}$

Jika dilakukan perbandingan dalam terjemahan di atas dan menimbang pertanyaan dan pernyataan yang diberikan oleh beberapa penafsir Tafsiran Alkitab Wycliffe, dan apa yang disampaikan oleh Dave Hagelberg, maka akan didapati perbedaan pengertian, contohnya dari Terjemahan Baru, dapat diartikan bahwa orang yang telah benar akan hidup melalui imannya atau ia akan menjalani hidup dengan imannya, ia mengatur hidupnya sesuai dengan apa yang ia inginkan dengan kata lain berdasarkan perbuatannya, sedangkan jika dilihat melalui tafsiran atau pengertian harafiah yang telah ditunjukan di atas, pengertian yang benar seharusnya adalah orang itu dibenarkan karena iman maka ia hidup dengan kata lain karena imanlah dia hidup, sebab iman itu membenarkannya dan karena itu dia dapat hidup.

Keadaan ini sering kali terjadi, di mana orang berusaha melakukan sesuatu agar memperoleh pembenaran untuk dirinya sendiri, Sebagai contoh, Martin Luther yang adalah seorang Tokoh Reformasi mengalami masalah dalam menerima kepastian keselamatan dari Allah, Luther setiap harinya melakukan perbuatan pertobatan dan mengakui dosa-dosanya. ${ }^{10} \mathrm{Hal}$ ini memang tidaklah salah, akan tetapi Luther sendiri mengakui bahwa ia melakukan hal ini bukanlah demi Allah melainkan demi kepentingan dirinya sendiri. Namun pada akhirnya Luther bertobat ketika menemukan farasa "orang benar karena iman akan hidup" dari Roma 1:17, yang kemudian merubah pandangan hidupnya terhadap Alkitab. ${ }^{11}$

Hal yang sama juga sering terjadi pada masa sekarang ini, di mana banyak orang percaya secara sadar maupun tidak sadar telah melakukan berbagai perbuatan yang baik demi mengejar pembenaran dari Allah, sehingga ini membawa orang-orang tidak menyadari betapa besar anugerah yang diberikan Allah kepada mereka. Orang-orang ini berusaha untuk hidup dengan baik untuk menerima pembenaran Allah, namun semua ini merupakan pengahrapan yang siasia. ${ }^{12}$ Sehingga frasa orang benar akan hidup oleh iman menjadi penting untuk dibahas.

Selain itu, ada permasalahan dalam menentukan tema Surat Roma, dimana menurut beberapa Ahli, bahwa pembenaran melalui iman ini merupakan tema surat Roma, ada juga yang berpendapat bahwa "pembenaran melalui iman" hanya merupakan sebuah doktrin pertempuran dan lebih memilih kepada kesatuan dalam Kritstus. ${ }^{13}$ Ini menunjukkan adanya perbedaan pandangan dalam menentukan tema surat Roma, sehingga Douglas dan Carson memberikan pandangan bahwa dengan menyoroti satu tema yang ada dalam Roma, maka dapat diberikan kesimpulan bahwa tema surat Roma adalah "Injil” yang terdapat pada Roma 1:16-17. Carson dan Douglas mengatakan bahwa "meskipun pembenaran akan iman bukanlah tema surat ini, kita tidak boleh lupa bahwa bagaimanapun juga itu merupakan unsur dari presentasi Paulus tentang Injil."14 Dari pendapat ini dapat disimpulkan bahwa orang benar akan hidup oleh iman yang juga terdapat dalam pasal 1:17 memiliki peran penting dalam surat Roma, dan merupakan poin penting untuk dibahas.

${ }^{9}$ Dave Hagelberg, Tafsiran Roma Dari Bahasa Yunani (Bandung: Kalam Hidup, 2013), 36.

${ }^{10}$ Bernard Lohse, Pengantar Sejarah Dogma Kristen: Dari Abad Pertama Sampai Masa Kini (Jakarta: BPK Gunung Mulia, 2008), 202.

${ }^{11}$ Lohse, 204.

${ }^{12}$ Sproul, 255.

${ }^{13}$ D. A. Carson dan Douglas J. Moo, An Introduction to the New Testament (Malang: Gandum Mas, 2016), 470.

${ }^{14}$ Carson dan Moo, 472. 
Oleh karena pengertian mengenai iman yang mulai bergesar yang membuat orang-orang secara sadar maupun tidak sadar berfokus kepada perbuatan dari pada kepada iman, adanya perbedaan terjemahan yang membuat kesalahan dalam mengartikan frasa "orang benar akan hidup oleh iman," dan ada beberapa masalah ketika menentukan tema surat Roma, maka sudah tentu akan sulit untuk memahami apa yang Paulus maksudkan tentang "orang benar akan hidup oleh iman" apa itu orang benar? Dan bagaimana orang benar ini dapat hidup melalui iman? Pengertian tentang iman yang mulai bergeser ini akan berpengaruh dengan pemaknaan yang Paulus inginkan mengenai orang benar akan hidup oleh iman. Hal ini juga membuat timbulnya pertanyaan mengenai frasa ini, apa yang menjadi alasan adanya frasa ini? Dan apa yang menjadi fungsi dari frasa ini? Mengapa orang yang benar karena iman akan hidup, dimunculkan dalam Surat Roma ini? Apa yang menjadi tujuan dari Paulus dalam memunculkan frasa ini di awal suratnya?

\section{Pokok Masalah}

Berdasarkan latar belakang masalah di atas, maka yang menjadi pokok masalah dalam penulisan skripsi ini adalah:

Pertama, Apa yang menjadi fungsi frasa orang benar akan hidup oleh iman berdasarkan Surat Roma?

Kedua, bagaimana implikasinya bagi orang percaya masa kini?

\section{Tujuan Penelitian}

Adapun yang menjadi tujuan dari penulisan skripsi ini adalah:

Pertama, untuk mengetahui serta menjelaskan fungsi frasa orang benar akan hidup oleh iman berdasarkan Surat Roma.

Kedua, untuk mengimplikasikannya ke kehidupan orang percaya masa kini.

\section{Manfaat Penelitian}

Adapun manfaat dari penulisan skripsi ini adalah:

Pertama, untuk memberikan pemahaman yang benar mengenai "orang benar akan hidup oleh iman" bagi orang percaya masa kini.

Kedua, untuk memberikan pemahaman kepada penulis mengenai "orang benar akan hidup oleh iman" dalam pelayan kedepannya.

Ketiga, untuk memenuhi salah satu persyaratan akademik dalam mencapai gelar S1 Teologi di Sekolah Tinggi Filsafat Theologia Jaffray Makassar.

\section{Metode Penelitian}

Adapun metode yang digunakan dalam penulisan skripsi ini adalah metode penelitian kulitatif melalui, prinsip-prinsip hermeneutik. Menurut kamus Webster hermeneutik adalah ilmu menafsir, atau ilmu yang menentukan arti dari perkataan atau frasa dari seorang penulis, lalu menjelaskannya kepada orang-orang lain, eksegesis, terutama berlaku untuk penafsiran ayat-ayat 
Kitab Suci. ${ }^{15}$ Sehingga metode ini merupakan metode yang sangat sesuai dalam penelitian yang dilakukan oleh penulis, dikarenakan penulis akan menganalisis perkataan Paulus mengenai orang benar akan hidup oleh iman berdasarkam Roma 1:16-17 dengan menggunakan metode hermeneutic untuk meneliti nas sebagai sumber utama yang akan diteliti yaitu dengan menggunakan Analisis konteks, Analisis struktur, Analisis teks, melalui pencarian makna dalam bahasa aslinya dan mengambil suatu kesimpulan teks itu. ${ }^{16}$ Selain itu penulis juga mencari dan menggunakan internet, jurnal-jurnal (online dan buku), dan kepustakaan (library research) atau penelitian perpustakaan yaitu membaca buku-buku, tafsiran-tafsiran dan menyelidiki kitab yang berkaitan dengan pokok bahasan skripsi ini. Penelitian dan buku yang relevan dengan penelitian ini yang berkaitan dengan frasa orang benar hidup karena iman. ${ }^{17}$

\section{Batasan Penelitian}

Dalam penulisan ini, penulis memberikan batasan tentang makna perkataan Paulus tentang "orang benar akan hidup oleh iman" berdasarkan Roma 1:16-17 dan cara hidup orang benar dalam surat Roma secara keseluruhan. Buku-buku atau tafsiran-tafsiran serta teori-teori yang berkembang mengenai pokok bahasan penulisan hanyalah sebagai referensi, acuan serta ide-ide yang akan membantu penulis untuk menyusun skripsi ini.

\section{Sistematika Penulisan}

Adapun sistematika dalam penulisan skripsi ini adalah sebagai berikut:

Bab I, merupakan pendahuluan yang berisikan latar belakang masalah, pokok masalah, tujuan penelitian, manfaat penelitian, metode penelitian, batasan penelitian dan sistematika penulisan.

Bab II, membahas latar belakang Surat Roma yang terdiri dari gambaran umum surat, penerima surat, keadaan jemaat, keunikan surat, tujuan penulisan surat, tempat dan waktu penulisan surat, tema surat, teologi surat, dan garis-garis besar surat.

Bab III, mengeksegesis dengan menggunakan metode penelitian kualitatif melalui metode hermeneutik yang berkaitan dengan latar belakang konteks (sebelum dan sesudah teks), struktur teks dan analisis teks dan lain-lain.

Bab IV, membahas tentang implikasi tentang orang benar akan hidup oleh iman bagi kehidupan orang percaya masa kini.

\footnotetext{
${ }^{15}$ Kevin J. Corner, Interpreting The Scripture (Malang: Gandum Mas, 2004), 1.

${ }^{16}$ Hengki Wijaya, Analisis Data Kualitatif Ilmu Pendidikan Teologi (Makassar: Sekolah Tinggi Theologia Jaffray Makassar, 2018); Hengki Wijaya, Metodologi Penelitian Pendidikan Teologi (Makassar: Sekolah Tinggi Theologia Jaffray Makassar, 2016).

${ }^{17}$ Hanny Frederik, "Konsep Persatuan Dengan Kematian Dan Kebangkitan Kristus Berdasarkan Roma 6:114," Jurnal Jaffray 13, no. 2 (September 29, 2015): 215-48, https://doi.org/10.25278/jj71.v13i2.179; Brian Marpay and Simon Alexander Tarigan, "Studi Alkitab Terhadap Sunat Dalam Roma 2:25-29; 3:1 Dan Implikasinya Bagi Kehidupan Kristen Masa Kini," Jurnal Jaffray 9, no. 1 (April 3, 2011): 164-87, https://doi.org/10.25278/jj71.v9i1.90; Yosua F. Camerling and Hengki Wijaya, "Misi Dan Kebangkitan Rohani: Implikasi Misi Allah Bagi Gereja," Jurnal Ilmiah Religiosity Entity Humanity (JIREH) 1, no. 1 (2019): 57-71; Daniel Ronda, Dasar Teologi Yang Teguh: Panduan Teologi Sistematika Di Perguruan Tinggi (Makassar: Sekolah Tinggi Theologia Jaffray Makassar, 2013); Daniel Ronda, "Ulasan Buku: Bagaimana Aku Dapat Meminta Allah untuk Kesembuhan Fisik?: Panduan Alkitabiah,” Jurnal Jaffray 13, no. 1 (March 28, 2015): 139-40, https://doi.org/10.25278/jj71.v13i1.118; Hengki Wijaya, "Pengenaan Manusia Baru Di Dalam Kristus: Natur, Proses, Dan Fakta Serta Implikasi Teologis Dan Praktisnya,” Jurnal Jaffray 14, no. 1 (March 22, 2016): 109, https://doi.org/10.25278/jj71.v14i1.194.
} 
Bab V, merupakan kesimpulan dan saran.

\section{Kesimpulan}

Setalah melalui banyak pembahasan, sekarang sampailah kepada kesimpulan dari apa yang telah Penulis tuliskan dalam bab-bab sebelumnya. Sebelum penulis memberikan kesimpulan, penulis ingin memberikan ringkasan singkat mengenai pembahasan pada bab-bab sebelumnya, khususnya pada Bab III, dan Bab IV.

Dalam Bab III, telah dibahas mengenai bagaimana keyakinan Paulus terhadap Injil, ia tidak malu terhadap Injil ini karena Injil adalah kekuatan Allah yang menyelamatkan, selain itu dibahas juga mengenai bahwa orang yang benar karena iman akan hidup, di mana orang benar ini adalah hubungan dan status yang diberikan Allah kepada setiap orang yang percaya kepada Kristus dan beroleh pembenaran.

Dalam Bab IV, dibahas mengenai betapa pentingnya hubungan baru yang diterima dari Allah karena Kristus Yesus, dan Iman kepada Kristus, serta bagaimana sikap orang percaya dalam menghadapi perkembangan zaman, yaitu dengan bersandar kepada TUHAN dan menyerahkan hidup kepada TUHAN serta tidak malu untuk mengakui Kristus.

Berdasarkan pembahasan-pembahasan yang telah Penulis bahas dalam bab-bab sebelumnya, maka Penulis menarik kesimpulan sebagai berikut:

Pertama, fungsi dari frasa orang benar akan hidup oleh iman adalah sebagai penanda status serta hubungan seseorang yang telah dibenarkan Allah dalam Kristus Yesus, dan pembenaran terjadi bukan dikarenakan tindakan atau perbuatan manusia melainkan hanya pemberian Tuhan semata. Melalui frasa ini juga akan ditemukan bagaimana pentingnya iman di dalam kehidupan setiap orang percaya, karena iman merupakan syarat untuk menerima pembenaran dari TUHAN.

Kedua, bagi setiap orang percaya yang telah dibenarkan Tuhan, seharusnya berjalan dengan iman selama dalam kehidupan dengan memahami apa yang dipercayainya serta menyatakannya dalam sepanjang kehidupannya, dan tidak malu untuk mengakui dirinya sebagai orang Kristen, seorang pengikut Kritus, karena Tuhan telah memberikan sesuatu yang sangat besar yang tidak dapat dibayarkan dengan apa pun. Dan setiap orang yang beriman kepada TUHAN harus mempercayai TUHAN secara terusmenerus selama dalam hidupnya.

\section{Saran-saran}

Adapun saran yang penulis berikan kepada para pembaca mengenai hasil penelitian dari Skripsi ini adalah sebagai berikut:

Pertama, Penulis melihat bagaimana perkembangan zaman sekarang ini yang semakin maju dan akan membawa kesulitan dalam memelihara iman kepada TUHAN. Oleh karena itu penulis menyarankan gereja-gereja untuk memperjelas pemahaman mengenai pembenaran, mengenai status orang percaya di hadapan TUHAN, pemeliharaan iman yang berlangsusng secara terus-menerus untuk dapat menghadapi perkembangan zaman ini. Kedua, Penulis mengharapkan setiap pembaca dan orang-orang percaya dapat mengerti bahwa tidak perlu malu untuk mengakui Kristus dalam sepanjang kehidupan ini.

Ketiga, Penulis menyadari bahwa dalam penulisan skripsi ini masih banyak terdapat banyak kekurangan, untuk itu ketika para pembaca menemukan apa yang kurang dalam penulisan ini, Penulis sangat mengharapkan saran yang dapat diberikan.

\section{Kepustakaan}

Alkitab Terjemahan Baru. Jakarta: Lembaga Alkitab Indonesia, 2015. Baird, William. "Romans 1:8-17." Expository Articles Interpretation. No 33 (5 November 2016): 398-403. Diakses 1 Juli 2019 https://doi.org/10.1177/002096437903300407. 
Barclay, William. Pemahaman Alkitab Setiap Hari: Surat Roma. Jakarta: BPK Gunung Mulia, 1986.

Berkhof, Louis. Teologi Sistematika 4: Doktrin Keselamatan. Surabaya: Momentum, 2014.

Boice, James Montgomery. Dasar-Dasar Iman Kristen. Surabaya: Momentum, 2015.

Camerling, Yosua F., and Hengki Wijaya. "Misi Dan Kebangkitan Rohani: Implikasi Misi Allah

Bagi Gereja.” Jurnal Ilmiah Religiosity Entity Humanity (JIREH) 1, no. 1 (2019): 57-71.

Carson, D. A, dan Douglas J. Moo. An Introduction to the New Testament. Malang: Gandum

Mas, 2016.

Chapman, Adina. Pengantar Perjanjian Baru. Bandung: Kalam Hidup, 2014.

"New Testament Greek Lexicon - New American Standard." Diakses 19 Juli 2019. https://www.biblestudytools.com/lexicons/greek/nas/dikaios.html.

Douglas, J. D. Ed. Tafsiran Alkitab Masa Kini Volume 3. Jakarta: Yayasan Komunikasi Bina Kasih/OMF, 1990.

End, Th. van den. Tafsiran Alkitab Surat Roma. Jakarta: BPK Gunung Mulia, 1995.

Enns, Paul. The Moody Handbook of Theology, Revised and Expanded (1). Malang: Literatur SAAT, 2014.

Erickson, Millard J. Teologi Kristen Volume 3. Malang: Gandum Mas, 2004.

Gunning, J. J. W. Tafsiran Alkitab Surat Yakobus. Jakarta: BPK Gunung Mulia, 2015.

Guthrie, Donald. Teologi Perjanjian Baru 2. Jakarta: BPK Gunung Mulia, 2003.

Hadiwijono, Harun. Iman Kristen. Jakarta: BPK Gunung Mulia, 2007.

Hagelberg, Dave. Tafsiran Roma dari bahasa Yunani. Bandung: Kalam Hidup, 2013.

Frederik, Hanny. "Konsep Persatuan Dengan Kematian Dan Kebangkitan Kristus Berdasarkan Roma 6:1-14." Jurnal Jaffray 13, no. 2 (September 29, 2015): 215-48. https://doi.org/10.25278/jj71.v13i2.179.

Henry, Matthew. Surat Roma; 1 \& 2 Korintus. Surabaya: Momentum, 2015.

Ibrahim, David. Tafsiran Surat Roma. Yogyakarta: ANDI, 2011.

Kee, Haword Clark. Ed. Alkitab Edisi Studi. Jakarta: Lembaga Alkitab Indonesia, 2010.

Lohse, Bernard. Pengantar Sejarah Dogma Kristen: dari abad pertama sampai masa kini. Jakarta: BPK Gunung Mulia, 2008.

Marpay, Brian, and Simon Alexander Tarigan. "Studi Alkitab Terhadap Sunat Dalam Roma 2:25-29; 3:1 Dan Implikasinya Bagi Kehidupan Kristen Masa Kini.” Jurnal Jaffray 9, no. 1 (April 3, 2011): 164-87. https://doi.org/10.25278/jj71.v9i1.90.

Marxsen, Willi. Pengantar Perjanjian Baru: Pendekatan Kritis Terhadap Masalah-Masalahnya. Jakarta: BPK Gunung Mulia, 2015.

Pfeiffer, Charles F., dan Everett F. Harrison. Ed. The Wycliffe Bible Commentary Volume 2. 5 ed. 2 vol. Malang: Gandum Mas, 2015. . The Wycliffe Bible Commentary Volume 3 Perjanjian Baru. Malang: Gandum Mas, 2013.

Piper, John. The Passion of Jesus Christ: Penderitaan Yesus Kristus. Surabaya: Momentum, 2013.

Prince, Derek. Iman yang Olehnya Kita Hidup. Jakarta: Yayasan Pekabaran Injil "Imanuel," 1994.

Ronda, Daniel. Dasar Teologi Yang Teguh: Panduan Teologi Sistematika Di Perguruan Tinggi. Makassar: Sekolah Tinggi Theologia Jaffray Makassar, 2013. 
_- "Ulasan Buku: Bagaimana Aku Dapat Meminta Allah untuk Kesembuhan Fisik?:

Panduan Alkitabiah.” Jurnal Jaffray 13, no. 1 (March 28, 2015): 139-40.

https://doi.org/10.25278/jj71.v13i1.118.

Santoso, Agus. Logos: Tata Bahasa Yunani Koine. Bandung: Bina Media Informasi, 2011.

Sproul, R. C. Kebenaran-Kebenaran Dasar Iman Kristen. Malang: Seminari Alkitab Asia Tenggara, 2000.

Stamps, Donald C. Ed. Alkitab Penuntun Hidup Berkelimpahan. Malang: Gandum Mas, 2015.

Suawa, Ferdinan K. Memahami Gramatika Dasar Bahasa Yunani Koine. Bandung: Kalam Hidup, 2009.

Sutanto, Hasan. Hermeneutik: Prinsip dan Metode Penafsiran Alkitab. Malang: Seminari Alkitab Asia Tenggara, 1998.

. Perjanjian Baru Interlinear Yunani-Indonesia dan Konkordansi Perjanjian Baru (PBIK) Jilid I. Jakarta: Lembaga Alkitab Indonesia, 2014. . Perjanjian Baru Interlinear Yunani-Indonesia dan Konkordansi Perjanjian Baru Jilid II. Jakarta: Lembaga Alkitab Indonesia, 2014.

Tenney, Merril C. Survey Perjanjian Baru. Malang: Gandum Mas, 2013.

Thiessen, Henry C. Teologi Sistematika. Malang: Gandum Mas, 1992.

Wijaya, Hengki. Analisis Data Kualitatif Ilmu Pendidikan Teologi. Makassar: Sekolah Tinggi Theologia Jaffray Makassar, 2018.

Wijaya, Hengki. Metodologi Penelitian Pendidikan Teologi. Makassar: Sekolah Tinggi Theologia Jaffray Makassar, 2016.

Wijaya, Hengki. "Pengenaan Manusia Baru Di Dalam Kristus: Natur, Proses, Dan Fakta Serta Implikasi Teologis Dan Praktisnya.” Jurnal Jaffray 14, no. 1 (March 22, 2016): 109. https://doi.org/10.25278/jj71.v14i1.194.

Zuck, Roy B. Basic Bible Interpretation. Malang: Gandum Mas, 2014. 